\title{
Pemanfaatan Ikan Asin Dalam Pembelajaran Bahasa Indonesia Di SD/MI
}

\author{
Farida Umu Ma'rifah ${ }^{1 *}$ \\ ${ }^{1}$ Program Studi Pendidikan Guru Madrasah Ibtidaiyah, Sekolah Pascasarjana IAIN Purwokerto, Indonesia \\ faridaumumarifah@gmail.com
}

\section{INFORMASI ARTIKEL}

\section{Data artikel:}

Naskah masuk, 25 Februari 2020

Direvisi, 21 April 2020

Diterima, 19 Agustus 2020

\section{Kata Kunci:}

\section{Ikan Asin}

Menulis

Sumber Belajar

Pembelajaran

\begin{abstract}
ABSTRAK
Abstract- The low ability of students to write sentences in Indonesia language learning is the background of this research. Salted fish learning resources are used to develop students' writing sentence skills. Salted fish as part of local wisdom is an important given to the education. This study aims to examine the effectiveness of the use salted fish learning resources to make sentences in Indonesian language learning. The study was conducted in class III SDN Tambakreja 02 Cilacap with 25 students, consisting of 12 male and 13 female students. Data collection techniques were observation, interview and documentation. The collected data were analyzed using qualitative analysis techniques. The result of the study prove that salted fish learning resources are effective in developing students' writing abilities. High student enthusiasm, seen from a pleasant atmosphere and student activity in the learning process. The percentage of students who score above KKM is $92 \%$ of 25 students.
\end{abstract}

\begin{abstract}
Abstrak- Rendahnya kemampuan siswa dalam menulis kalimat pada pembelajaran Bahasa Indonesia melatarbelakangi penelitian ini. Sumber belajar ikan asin digunakan untuk menumbuhkembangkan kemampuan menulis kalimat pada siswa. Ikan asin sebagai bagian dari kearifan lokal menjadi bagian yang penting diberikan pada satuan pendidikan agar peserta didik tidak kehilangan nilai dasar kulturalnya. Penelitian ini bertujuan untuk menguji efektivitas pemanfaatan sumber belajar ikan asin pada materi membuat kalimat dalam pembelajaran Bahasa Indonesia. Penelitian dilaksanakan di kelas III SDN Tambakreja 02 Cilacap dengan jumlah siswa 25 orang, terdiri dari 12 siswa laki-laki dan 13 siswa perempuan. Teknik pengumpulan data yang dilakukan yaitu observasi, wawancara dan dokumentasi. Data yang terkumpul dianalisis menggunakan teknik analisis kualitatif. Hasil penelitian menunjukkan bahwa, sumber belajar ikan asin efektif dalam menumbuhkembangkan kemampuan menulis siswa. Antusiasme siswa yang tinggi, terlihat dari suasana yang menyenangkan dan keaktifan siswa dalam proses pembelajaran. Prosentase siswa yang medapatkan nilai di atas KKM sebanyak $92 \%$ dari 25 siswa.
\end{abstract}




\section{Korespondensi:}

\section{Farida Umu Ma'rifah}

Program Studi Pendidikan Guru Madrasah Ibtidaiyah, IAIN Purwokerto, Indonesia Jl. A. Yani No. 40A, Karanganjing, Purwanegara, Kec. Purwokerto Utara, Banyumas, Indonesia

\section{PENDAHULUAN}

Menulis merupakan salah satu keterampilan berbahasa yang paling sulit jika dibandingkan tiga keterampilan bahasa lainnya. Hal tersebut selaras dengan pendapat Nurgiyantoro (Trawoco, Suryanto, and Hastuti 2016) bahwa dibanding tiga kemampuan berbahasa yang lain, ketrampilan menulis lebih sulit dikuasai, sekalipun oleh penutur asli bahasa yang bersangkutan. Kemampuan menulis menghendaki penguasaan berbagai macam unsur intrinsik dan ekstrinsik kebahasaan yang akan menjadi karangan..

Pelly mengatakan bahwa pelajaran membaca dan menulis yang dulu merupakan pelajaran dan latihan pokok kini kurang mendapat perhatian, baik dari para siswa maupun para guru (Zamzani 1996). Pembelajaran Bahasa Indonesia kurang ditangani secara sungguh-sungguh. Akibatnya, banyak ditemukan siswa yang memiliki kemampuan berbahasa Indonesia yang rendah. Rendahnya kualitas keterampilan menulis siswa disebabkan oleh kenyataan bahwa pengajaran menulis dianaktirikan. (Darusuprapti 2017). Hal tersebut sejalan dengan realita bahwa masih banyak ditemukan guru di sekolah-sekolah yang belum menyadari pentingnya latihan menulis sebagai salah satu usaha meningkatkan kemampuan berbahasa siswa. Selama ini ada kecenderungan pembelajaran Bahasa Indonesia terlalu diarahkan pada segi-segi teori saja dari pada latihan menulis, sehingga pengajaran menulis tidak akan tercapai dengan baik tanpa adanya latihan-latihan. Rendahnya pengetahuan guru dalam menemukan sumber, media, dan metode belajar yang tepat untuk menyampaikan materi menulis juga menjadi pemicu rendahnya minat siswa dalam menulis.

Menulis adalah sebuah kegiatan yang digunakan untuk menggali pikiran dan perasaan mengenai suatu objek, memilih halhal apa yang akan ditulis, dan menuliskannya sehingga pembaca akan mudah memahaminya dengan jelas (Indihadi 2018). Kegiatan menulis pada dasarnya bukan hanya untuk melahirkan sebuah pemikiran dan perasaan saja, melainkan juga pengungkapan ide pengetahuan ilmu serta pengalaman hidup seseorang dalam bahasa tulis. Oleh karena itu, menulis bukan kegiatan yang sederhana dan tidak perlu dipelajari, akan tetapi justru dikuasai.

Mengembangkan keterampilan menulis menjadi sebuah kegemaran diperlukan kondisi yang mendukung. Kondisi belajar seperti yang dikemukakan Cambourne (Setiabudi and Jakarta 2017) merupakan pengembangan penelitian linguistik, yaitu studi pemerolehan bahasa. Jika guru dapat memahami dan mengaplikasikan teori itu, siswa akan memiliki perubahan dalam keterampilan dan strategi pengembangan kebahasaan. Cambourne menjelaskan istilah kondisi merupakan keadaan tertentu (melakukan, berperilaku, menciptakan), yang merupakan kesatuan utuh dan bersinergi, saling mempengaruhi antara yang satu dan yang lain. Kondisi-kondisi tersebut yaitu: (1) penenggelaman (immersion); (2) pemodelan (demonstration); (3) keterlibatan (engagement); (4) harapan (expectation); (5) tanggung jawab (responsibility); (6) penggunaan/ pengkaryaan (employment); (7) penghampiran (approximation); dan (8) tanggapan (response).

Keterampilan menulis menjadi salah satu pokok bahasan dalam pelajaran Bahasa Indonesia di sekolah yang harus benar-benar 
diajarkan secara tepat. Berdasarkan indikator tersebut tentunya seorang guru dituntut untuk kreatif dalam menyampaikan materi pembelajaran, agar materi menjadi menarik di mata siswa. Ketertarikan siswa dapat dimunculkan salah satunya menggunakan sumber belajar yang menarik dan nyata.

Berdasarkan pemaparan di atas penulis mempunyai gagasan untuk menggunakan ikan asin sebagai sumber belajar dalam mengajarkan pelajaran Bahasa Indonesia. Sumber Belajar adalah sesuatu yang dapat mengandung pesan untuk disajikan melalui penggunaan alat ataupun oleh dirinya sendiri dapat pula merupakan sesuatu yang digunakan untuk menyampaikan pesan yang tersimpan di dalam bahan pembelajaran yang akan dberikan (Hafid 2011).

Jenis sumber belajar dibagi dua yaitu: Pertama, sumber belajar yang sengaja direncanakan (learning resources by design), merupakan semua sumber yang secara khusus dikembangkan sebagai komponen sistem instruksional dalam rangka memberikan fasilitas belajar yang terarah serta bersifat formal. Kedua, sumber belajar yang karena dimanfaatkan (learning resources by utilization), yakni sumber belajar yang tidak secara khusus di desain dalam rangka memenuhi keperluan pembelajaran tetapi dapat ditemukan, diaplikasikan, dan dimanfaatkan demi terpenuhinya keperluan belajar(Rusman 2008).

Ikan asin termasuk ke dalam jenis sumber belajar yang dimanfaatkan (learning resources by utilization), karena banyak dijumpai dalam kehidupan masyarakat khususnya daerah pesisir Cilacap. Ikan asin merupakan salah satu sumber belajar yang kontekstual. Dimana menurut Piaget anak usia Sekolah Dasar (SD) berada pada tahap operasional konkret. Tahap operasional konkret ditandai dengan adanya sistem operasi berdasarkan apa yang kelihatan nyata/konkret (Paul Suparno 2001).

Oleh karena itu peneliti memiliki gagasan untuk menggunakan ikan asin sebagai sumber belajar. Melihat ikan asin merupakan suatu makanan tradisional kota Cilacap yang notabennya wilayah pesisir. Pengangkatan sumber belajar lokalitas diharapkan dapat mengenalkan siswa terhadap lingkungannya dan menumbuhkembangkan rasa memiliki dan mencintai daerahnya.

Penelitian ini akan dilaksanakan di SD Negeri Tambakreja 02 Cilacap. Objek penelitiannya yaitu mengambil sampel anak kelas III yang berjumlah 25 orang siswa. Adapun lingkup materinya yaitu pelajaran Bahasa Indonesia khususnya dalam KD 3.1 yaitu menggali informasi konsep perubahan wujud benda dalam kehidupan sehari-hari yang disajikan dalam bentuk lisan, tulis, visual dan atau eksplorasi lingkungan dan KD 4.1 Menyajikan hasil informasi tentang konsep perubahan wujud benda dalam kehidupan sehari-hari dalam bentuk lisan, tulis, dan visual menggunakan kosakata baku dan kalimat efektif.

Siswa nantinya akan diminta untuk mengobservasi ikan asin yang dijadikan sumber belajar. Dari observasi ikan asin tersebut siswa diminta untuk mengisi lembar observasi yang disediakan untuk menuliskan ciri-ciri ikan asin, dan membuat kalimat berdasarkan ciri-ciri yang telah didapatkan. Penelitian ini bertujuan untuk menguji seberapa efektivitas pemanfaatan sumber belajar ikan asin dalam menumbuhkembangkan kemampuan membuat kalimat pada pembelajaran Bahasa Indonesia.

Kalimat merupakan kunci awal untuk membuat sebuah karya tulis baik ilmiah maupun non ilmiah. Oleh karena itu penulis memilih pemanfaatan ikan asin sebagai pemantik untuk mengembangkan kemampuan siswa dalam membuat kalimat.

Berdasarkan masalah yang telah dipaparkan, diperoleh rumusan masalah sebagaimana berikut: Pertama, bagaimana pemanfaatan ikan asin dalam pembelajaran Bahasa Indonesia pada KD 3.4 di kelas III?. Kedua, bagaimana pemanfaatan ikan asin 
dalam pembelajaran Bahasa Indonesia pada KD 4.4 di kelas III?

\section{METODE PELAKSANAAN}

Penelitian ini menggunakan metode kualitatif dengan jenis penelitian tindakan. merupakan penelitian tindakan yang menekakan pada kegiatan (tindakan) dengan mengujicobakan suatu pemikiran ke dalam praktek atau situasi nyata dalam skala mikro yang diharapkan kegiatan tersebut mampu memperbaiki, meningkatkan kualitas, serta melakukan perbaikan sosial (Zuriah 2003). Subjek penelitian ini adalah siswa kelas 3 di SD Negeri Tambakreja 02 Cilacap, dengan jumlah siswa 25 orang..

Teknik pengumpulan data yang digunakan dalam penelitian ini yaitu: Pertama, observasi, digunakan untuk memperoleh data dengan cara pengamatan secara langsung pada proses pembelajaran bahasa Indonesia dengan memanfaatkan ikan asin sebagai sumber belajar. Kedua, wawancara, dilakukan untuk menggali informasi dari pelaku yang terlibat dalam proses pembelajaran pemanfaatan ikan asin dalam pembelajaran bahasa Indonesia. Wawancara diberikan pada guru dan beberapa sampel yang diambil dari peserta didik. Ketiga, dokumentasi, dalam penelitian ini dokumen yang digunakan adalah RPP, silabus, foto proses belajar, portofolio siswa, dan hasil belajar siswa.

Teknik analisis data dalam penelitian ini menggunakan analisis model Miles dan Huberman (P.D 2014), dengan langkah reduksi data (reduction drawing), penyajian data (data display), dan verifikasi data (consullution drawing). Reduksi data dalam penelitian ini yaitu memilih dan memilah data mana saja yang perlu digunakan. Selanjutnya, menyajikan data yang telah di reduksi dalam bentuk narasi yang mana akan memudahkan dalam memahami dan menganalisis data. Terakhir, verifikasi data, yaitu penarikan kesimpulan dengan data-data yang yang valid sehingga penelitian pemanfaatan ikan asin sebagai sumber belajar Bahasa Indonesia di kelas tiga dikategorikan sebagai penelitian yang kredibel. Adapun tahapan pelaksanaan dilakukan sebagai berikut:

Pertama adalah guru menjelaskan tentang bagaimana cara membuat kalimat yang benar tanpa media. Selanjutnya, diberikan pre test kepada siswa untuk membuat kalimat yang berkaitan tentang benda disekitar tempat tinggal. Pretes dilakukan untuk mengetahui seberapa jauh kemampuan siswa akan materi membuat kalimat.

Kedua, guru menyediakan ikan asin untuk diamati oleh siswa, kemudian siswa diminta untuk mengidentifikasi ikan asin sesuai dengan jenis bendanya.

Ketiga, siswa diminta untuk menuliskan ciri-ciri ikan asin dalam lembar portofolio. Dari ciri-ciri yang telah di dapat, kemudian siswa diminta untuk membuat kalimat.

Keempat, dilakukan verifikasi dan klarifikasi terhadap data hasil pengamatan siswa.

\section{HASIL DAN PEMBAHASAN}

Pembelajaran Bahasa Indonesia di kelas tiga sebagian masih dibawah rata-rata KKM (Kriteria Ketuntasan Minimal). Hal tersebut dibuktikan dengan data yang diberikan guru kelas tiga bahwa, nilai UTS Semester I dari 25 orang siswa ditemukan 8 anak yang mendapat nilai dibawah KKM dengan KKM mata pelajaran Bahasa Indonesia yaitu 75 . Berdasarkan hasil wawancara dengan guru kelas tiga banyak ditemukan siswa yang sering mengantuk dan antusiasme yang rendah akan pembelajaran Bahasa Indonesia. Hal tersebut dikarenakan pelajaran Bahasa Indonesia sudah memiliki label dengan bacaannya yang banyak dan membosankan. Ditambah dengan kemauan guru yang rendah dalam mengkreasikan sumber belajar, strategi dan metode pembelajarannya. Penulis menemukan bahwa guru kelas tiga masih menggunakan sumber belajar yang seadanya yaitu buku cetak, LKS dan pengetahuan guru. 
Anak kelas 3 SD/MI merupakan anak yang masih senang bermain dan menggunakan motoriknya. Pada usia ini merupakan tahap operasional konkrit, yang mana siswa membutuhkan benda-benda nyata dalam memahami suatu konsep keilmuan yang dimilikinya. Oleh karena itu, peneliti menggunakan ikan asin sebagai sumber belajar dalam pembelajaran Bahasa Indonesia.

Ikan asin merupakan bahan makanan yang terbuat dari daging ikan yang diberi banyak garam agar awet. Ikan asin banyak ditemukan di daerah pesisir laut. Salah satunya di daerah pesisir pantai Teluk Penyu yang mana menjadi makanan khas daerah Cilacap. Ada banyak jenis ikan yang dapat dibuat menjadi ikan asin, dalam penelitian ini peneliti mengambil jenis ikan layur. Ikan layur merupakan ikan yang mudah ditemukan karena menangkapnya tidak mengenal waktu-waktu khusus seperti ikan yang lain. Selain itu, harga yang ekonomis juga menjadi pertimbangan peneliti dalam memilih ikan tersebut.

Penelitian ini dilaksanakan di SD Negeri Tambakreja 02 Cilacap. Subjek penelitian ini adalah 25 orang siswa kelas 3 terdiri dari 13 orang laki-laki dan 12 orang perempuan. Strategi pembelajaran dilakukan secara indoor. Pembelajaran indoor dilakukan di dalam ruang kelas dengan memberikan pengetahuan awal tentang jenis benda, membuat kalimat dan pertanyaan. Kemudian pretes diberikan tanpa menggunakan media, banyak ditemukan siswa yang kebingungan, ditandai dengan 11 siswa yang bertanya pada guru. Berikut tabel data hasil pre test.

Tabel 1. Deskripsi Hasil Pre Test Siswa Kelas 3

\begin{tabular}{|l|l|l|l|}
\hline No. & $\begin{array}{l}\text { Jumlah } \\
\text { Siswa }\end{array}$ & Nilai & $\begin{array}{l}\text { Kriteria } \\
\text { Ketuntasan (KKM } \\
75)\end{array}$ \\
\hline 1 & 3 & 90 & Tuntas \\
\hline 2 & 3 & 80 & Tuntas \\
\hline 3 & 2 & 70 & Belum Tuntas \\
\hline
\end{tabular}

\begin{tabular}{|l|l|l|l|}
\hline 4 & 4 & 60 & Belum Tuntas \\
\hline 5 & 6 & 50 & Belum Tuntas \\
\hline 6 & 7 & 40 & Belum Tuntas \\
\hline & $\begin{array}{l}\text { Rata- } \\
\text { rata }\end{array}$ & 84 & \\
\hline
\end{tabular}

Berdasarkan tabel hasil pre test di atas diketahui bahwa terdapat 19 siswa yang belum tuntas. Hal tersebut menandai bahwa masih banyak siswa yang belum paham akan materi membuat kalimat.

Tahapan pembelajaran berhubungan dengan berbagai kegiatan di lingkungan yang bertujuan meningkatkan kapasitas belajar siswa. Rancangan pembelajaran memberikan kesempatan pada siswa untuk belajar lebih mendalam melalui kegiatan observasi benda yang sering dijumpai di lingkungan sekitar sekolah. Pembelajaran tersebut membantu anak untuk mengaplikasikan pengetahuan yang dimilikinya, sehingga akan menjembatani antara teori dan fakta yang terjadi di lingkungan sekitar. Kualitas pembelajaran yang menyajikan situasi nyata akan memberikan peningkatan kapasitas pencapaian belajar dan membangun ketrampilan sosial dan personal yang lebih baik (Feiman 1973).

Berdasarkan pengamatan peneliti dari proses pembelajaran yang telah diamati, terlihat siswa memiliki antusiasme yang tinggi. Hal tersebut ditandai dengan suasana yang menyenangkan dan keaktifan siswa dalam proses pembelajaran yang tinggi. Adapun siswa yang sebelumnya kesulitan dalam membuat kalimat, setelah penggunaan sumber belajar ikan asin menjadi mudah membuatnya. Hal tersebut dibuktikan ketika guru meminta siswa minimal menuliskan sepuluh kalimat dari ciri-ciri yang sudah siswa dapatkan. Hasil portofolio siswa banyak ditemukan yang menuliskan lebih dari sepuluh ciri-ciri dan kalimatnya. Hasil penilaian siswa digambarkan pada tabel di bawah ini: 
Tabel 2. Deskripsi Hasil Belajar Siswa Kelas 3

\begin{tabular}{|l|l|l|l|}
\hline No. & $\begin{array}{l}\text { Jumlah } \\
\text { Siswa }\end{array}$ & Nilai & $\begin{array}{l}\text { Kriteria Ketuntasan } \\
(\text { KKM 75) }\end{array}$ \\
\hline 1 & 13 & 100 & Tuntas \\
\hline 2 & 2 & 90 & Tuntas \\
\hline 3 & 2 & 85 & Tuntas \\
\hline 4 & 4 & 80 & Tuntas \\
\hline 5 & 2 & 75 & Tuntas \\
\hline 6 & 2 & 70 & Belum Tuntas \\
\hline & $\begin{array}{l}\text { Rata- } \\
\text { rata }\end{array}$ & 84 & \\
\hline
\end{tabular}

Berdasarkan tabel di atas diketahui bahwa hasil belajar siswa tentang materi jenis, ciri-ciri benda dan membuat kalimat menggunakan sumber belajar ikan asin menunjukan hasil maksimal. Dari total 25 orang siswa terdapat 23 siswa sudah memenuhi standar ketuntasan minimal dengan prosentase $92 \%$. Sedangkan 2 siswa belum memenuhi standar ketuntasan minimal dengan prosentase $8 \%$.

Sumber belajar yang diambil dari produk lokal dan menggunakan strategi pembelajaran yang dikembangkan melibatkan siswa untuk belajar secara aktif dalam mengonstruksi pengetahuan melalui pendekatan penemuan dan penyelidikan. Selama proses pembelajaran, siswa memperoleh pemahaman konsep melalui interaksi langsung dengan ikan asin sehingga akan mendorong siswa untuk mengkontruksi pemahamannya berdasarkan pengalaman belajar. Melalui pembelajaran tersebut siswa diarahkan untuk memahami produk-produk lokal dengan cara mengenalkan produk lokal, mengamati, dan mengobservasi ciri-ciri benda dengan tepat. Pembelajaran yang dilakukan tidak hanya menekankan pada penguasaan konsep, tetapi menumbuhkan rasa ingin tahu siswa, sehingga termotivasi untuk melakukan pengamatan atau penyelidikan.

Sumber pembelajaran berbasis kearifan lokal adalah sumber pembelajaran yang menerapkan pendekatan kontesktual. Pada pembelajaran tersebut memaparkan fenomena atau fakta yang ditemukan disekitar lingkungan siswa dan materi bahasan yang dipelajari berkaitan dengan kenyataan praktis yang ditemukannya dalam kehidupan seharihari. Pembelajaran dengan pendekatan kontekstual melatih siswa dalam menemukan hubungan antara gagasan abstrak dengan halhal yang praktis (aplikatif) dalam konteks yang nyata, dan menginternalisasi konsep melalui proses eksperimen (Mooij 2007) Pembelajaran kontekstual berasumsi bahwa secara natural pikiran seseorang akan mencari makna yang sesuai dengan situasi lingkungan nyata dan memberi manfaat terhadap lingkungan (Balım 2009). Pembelajaran kontekstual adalah satu konsepsi pembelajaran yang mengaitkan subjek yang dipelajari dengan situasi yang nyata, sehingga siswa akan mampu mengaplikasikan pengetahuannya dalam kehidupan sehari-hari.

Merujuk pada hasil penelitian, sumber pembelajaran yang telah dikembangkan telah memotovasi siswa untuk belajar secara aktif. Kegiatan pembelajaran dengan melakukan observasi ikan asin dapat meningkatkan sikap ilmiah yang baik dan menumbuhkan paradigma yang positif terhadap lingkungan dan kecenderungan berpartisipasi terhadap pelestarian produk lokal. Sumber pembelajaran berbasis kearifan lokal yang dikembangkan diharapkan dapat menumbuhkan perilaku peserta didik yang ramah terhadap lingkungan dan mencintai produk lokal.

\section{KESIMPULAN}

Kondisi Cilacap yang dekat dengan pesisir laut menjadikan melimpahnya poduk hasil laut. Melimpahnya hasil laut sebagian diolah menjadi ikan asin oleh masyarakat agar tidak mudah busuk. Hal itu menjadikan kota 
Cilacap sebagai kota penghasil ikan asin. Ikan asin sangat memadai untuk dijadikan sumber belajar untuk mendukung proses dan pencapaian tujuan pembelajaran tentang konsep dasar jenis benda, ciri-ciri benda dan membuat kalimat.

Sumber belajar ikan asin digunakan efektif dalam menumbuhkembangkan kemampuan menulis siswa pembelajaran Bahasa Indonesia. Hal itu dibuktikan dari proses pembelajaran yang telah diamati, terlihat siswa memiliki antusiasme yang tinggi ketika diberi media dalam pembelajaran membuat kalimat dibanding ketika guru menjelaskan tanpa media. Suasana yang menyenangkan dan keaktifan siswa terlihat dalam proses pembelajaran.

Siswa yang tidak tuntas saat pre test tanpa menggunakan media ikan asin terdapat 19 anak atau $76 \%$ yang di bawah kkm, sedangkan yang di atas $\mathrm{kkm} 5$ anak atau 20\%. Adapun nilai setelah guru mengajarkan menggunakan media ikan asin terjadi peningkatan pada hasil belajar siswa. Siswa yang medapatkan nilai di atas KKM sebagai bentuk hasil belajar dengan sumber belajar ikan asin sebanyak $92 \%$ atau 23 siswa dan yang di bawah kkm sebanyak $8 \%$ atau 2 orang siswa dari 25 siswa. Sumber belajar ikan asin menumbuhkan paradigma yang positif terhadap kecintaan produk lokal. Hal tersebut akan menumbuhkan siswa yang ramah dan mengenal lingkungan sekitarnya dengan baik.

\section{DAFTAR PUSTAKA}

Balım, Ali Günay. 2009. "The Effects of Discovery Learning on Students , Success and Inquiry Learning Skills." Eurasian Journal of Educational Research.

Darusuprapti, Fajarsih. 2017. "Peningkatan Keterampilan Menulis Cerita Pendek Menggunakan Media Pop Up Untuk Siswa Kelas Iv Sd Muhammadiyah Sidokarto Godean Sleman Yogyakarta." Jurnal Pendidikan Guru Sekolah Dasar.

Feiman, Sharon. 1973. "Models of Teaching .
Bruce Joyce , Marsha Weil ." The School Review.

Hafid, H. ab. 2011. "Sumber Dan Media Pembelajaran." Jurnal Sulesana.

Indihadi, Dian. 2018. "Penggunaan Media Gambar Terhadap Pembelajaran Menulis Puisi Peserta Didik." PEDADIDAKTIKA: Jurnal Ilmiah Pendidikan Guru Sekolah Dasar 5(1):193-205.

Mooij, Ton. 2007. "Contextual Learning Theory: Concrete Form and a Software Prototype to Improve Early Education." Computers and Education.

P.D, Sugiono. 2014. Metode Penelitian Pendidikan Pendekatan Kuantitatif.Pdf.

Paul Suparno. 2001. Teori Perkembangan Kognitif Jean Piaget. Yogyakarta: Kanisius.

Rusman. 2008. "Manajemen Kurikulum, Bandung." Program Studi Pengembangan Kurikulum Sekolah Pasca Sarjana Universitas Pendidikan Indonesia.

Setiabudi, Jalan, and No Jakarta. 2017. "PEMBELAJARAN MENULIS DI SEKOLAH DASAR Gusti Yarmi PGSD Universitas Negeri Jakarta.” 31(1):1-6.

Trawoco, Kukuh Fajar, Edy Suryanto, and Sri Hastuti. 2016. "Peningkatan Kemampuan Menulis Paragraf Deskripsi Dengan Model Example Non-Example Pada Siswa Sekolah Menengah Kejuruan." Jurnal Penelitian Bahasa, Sastra Indonesia, Dan Pengajarannya.

Zamzani, Haryadi \&. 1996. Peningkatan Keterampilan Berbahasa Indonesia. Yogyakarta: Depdikbud.

Zuriah. 2003. Penelitian Tindakan Dalam Bidang Pendidikan Dan Sosial. Malang: Banyu Publishing. 